\title{
PRESERVATION AND MACERATION OF AMAZON AÇAI LEAFLET TISSUE TO OBTAIN GENOMIC DNA
}

\author{
PRESERVAÇÃO E MACERAÇÃO DE TECIDO DE FOLÍOLOS DE AÇAÍ DA \\ AMAZÔNIA PARA OBTENÇÃO DE DNA GENÔMICO
}

\section{Hellen Sandra Freires da Silva AZÊEEDO'루 Polinar Bandeira RUFINO²; José Marlo Araújo de AZEVEDO ${ }^{3}$; Luciélio Manoel da SILVA; Lúcia Helena de Oliveira WADT ${ }^{5}$; Tatiana de CAMPOS $^{6}$}

1. Doutoranda em Biodiversidade e Biotecnologia - Fundação Oswaldo Cruz - FIOCRUZ, Rede Bionorte, Porto Velho, RO, Brasil, hellenfreires@gmail.com; 2. Graduada em Biomedicina - Faculdade Meta - FAMETA, Rio Branco, AC, Brasil.; 3. Professor, Doutor, Instituto Federal do Acre - IFAC, Cruzeiro do Sul, AC, Brasil.; 4. Analista da Empresa Brasileira de Pesquisa Agropecuária - Embrapa Acre, Rio Branco, AC, Brazil.; 5. Pesquisadora, Doutora, Empresa Brasileira de Pesquisa Agropecuária - Embrapa Rondônia, Porto Velho, RO, Brasil.; 6. Pesquisadora, Doutora, Empresa Brasileira de Pesquisa Agropecuária - Embrapa Acre, Rio Branco, AC, Brasil, tatiana.campos@embrapa.br.

\begin{abstract}
The objective of this study was to test the efficiency of preservation and maceration methods for Euterpe precatoria leaflet tissue to obtain genomic DNA for molecular studies. The leaflets of $E$. precatoria were collected in an experimental field at Embrapa Acre, Brazil. The study was conducted in a completely randomized design with 10 replicates, in a $12 \times 2$ factorial structure, with 12 storage treatments (fresh; lyophiliser 3 days; refrigerator 3, 5, and 7 days; silica gel 7, 10, 20, and 30 days; and transport buffer 3, 5 , and 7 days) and two leaf tissue maceration methods (liquid nitrogen and the TissueLyser®). Statistically significant differences in the obtained DNA concentration were found between the maceration and storage treatments. The TissueLyser ${ }^{\circledR}$ macerator produced higher DNA concentrations when compared to liquid nitrogen. For the storage treatments, five groups were formed based on DNA concentration when macerated with the TissueLyser ${ }^{\circledR}$ and two groups when macerated with liquid nitrogen. The DNA concentrations ranged from $285.00 \mathrm{ng} / \mu \mathrm{L}$ ( 7 days in transport buffer) to $702.00 \mathrm{ng} / \mu \mathrm{L}$ (30 days in silica gel) when the leaflets were macerated with liquid nitrogen, and from $572.73 \mathrm{ng} / \mu \mathrm{L}$ (30 days in silica gel) to $2,850.00 \mathrm{ng} / \mu \mathrm{L}$ (3 days in lyophiliser) using the TissueLyser ${ }^{\circledR}$ macerator. The DNA purity (A260/A280 nm) varied from 1.30 to 1.70 when the leaflets were macerated with liquid nitrogen and from 1.30 to 1.90 with the TissueLyser® macerator. Despite the variations in leaf tissue preservation and DNA concentration, all treatments were effective for DNA isolation and it was possible to amplify genomic regions of microsatellite markers by PCR. It was concluded that leaflets of E. precatoria stored in a lyophiliser and processed with an automatic macerator resulted in satisfactory DNA for molecular studies.
\end{abstract}

KEYWORDS: Açaí-solteiro. CTAB method. DNA isolation. Euterpe precatoria.

\section{INTRODUCTION}

The açaizeiro (Euterpe precatoria Mart.), popularly known as açaí-solteiro or açaí-doamazonas, is a single-stemmed palm tree belonging to the family Arecaceae. It is found naturally in the northern region of Brazil, in the states of Acre, Rondônia, Amazonas, and Pará. It occurs as solitary stems in large populations with different density levels in flooded and dryland areas (BUSSMANN; ZAMBRANA, 2012).

The E. precatoria species has multiple uses including palm heart extraction, production of biojewellery, and use in medicine. The most utilised part is the mesocarp, from which a thick liquid known as "açaí juice" is extracted. This liquid is very nutritious and has a high calorific value
(YUYAMA et al., 2011). It is widely consumed in the Brazilian Amazon within all socioeconomic levels of the population. In the international market, it has been highly regarded for its nutritional qualities, being rich in phenolic compounds, anthocyanins, and substances with high antioxidant elements (YAMAGUCHI et al., 2015). Despite its importance, the exploitation of E. precatoria is still extractivism-based.

For this reason, genetic analyses are of great importance since they can increase knowledge of the diversity, genetic structure, and crossing rate of natural populations. Molecular markers are useful tools to define appropriate conservation and management strategies, and to inform the collection of germplasm for use in breeding programs (SARTORETTO; FARIAS, 2010). 
The method of tissue maceration may affect the quality of the DNA obtained and most studies use liquid nitrogen or automatic macerators. However, liquid nitrogen is not always easily accessible because its transport involves the risk of explosion, it must be stored in special containers, and it is expensive. These factors limit the routine use of liquid nitrogen in many laboratories, including those located in the Amazon. Several studies have investigated alternative methods to macerate leaflets, especially in fibrous palms (IBRAHIM et al., 2010; IHASE et al., 2016). Ibrahim et al. (2010) used sterilized sand with buffer to macerate mature leaves of date palm (Phoenix dactylifera). Ihase et al. (2016) macerated leaves of oil palm (Elaeis guineensis) in a crucible with buffer. Both studies were successful in extracting DNA.

We are not aware of any previous studies of the storage and maceration of leaflet tissue in $E$. precatoria. The development of simpler and cheaper alternative methods to obtain DNA of sufficient quantity and quality is essential for molecular studies. The objective of this study was to test the efficiency of various preservation and maceration methods on E. precatoria leaflet tissue to obtain genomic DNA for molecular studies.

\section{MATERIAL AND METHODS}

To evaluate different methods of storage and maceration, mature leaflets were collected from an experimental field at Embrapa Acre, Rio Branco, AC, Brazil. The study was conducted in a completely randomized design with 10 replicates, in a $12 \times 2$ factorial design, with 12 storage treatments (fresh; lyophiliser 3 days; refrigerator 3, 5, and 7 days; silica gel 7, 10, 20, and 30 days; and transport buffer 3, 5, and 7 days) and two leaf tissue maceration methods (liquid nitrogen and TissueLyser®).

For the silica gel treatments, silica gel was used to dehydrate the leaflets over four different periods $(7,10,20$, and 30 days). The samples were stored in a plastic bag and kept out of the light at an average temperature of $27{ }^{\circ} \mathrm{C}$. The silica gel was replaced as necessary according to the saturation indicator. Fresh leaflets were stored in microtubes and cooled with ice. In the lyophiliser treatment, leaflets were dehydrated in a lyophiliser (Terroni Enterprise II) for $72 \mathrm{~h}$.

The six remaining treatments were stored in a refrigerator: leaflets wrapped in newspaper changed daily and stored in plastic bags for 3,5, and 7 days; and leaflets stored for 3, 5, and 7 days in microtubes containing $1 \mathrm{~mL}$ of transport buffer $(300$ $\mu \mathrm{l}$ of CTAB $2 \%$ buffer; $700 \mu \mathrm{l}$ of absolute ethanol).

Leaf tissues subjected to the twelve storage treatments were macerated using two methods: I) Mechanical maceration (TissueLyser ${ }^{\circledR}$, Qiagen): the leaflets were cut into small pieces with scissors and placed in Eppendorf tubes containing two stainless steel spheres and $2 \% \mathrm{CTAB}$, then the microtubes were packed in the TissueLyser ${ }^{\circledR}$ machine; II) Maceration with liquid nitrogen: the leaflets were placed in a porcelain mortar, then macerated with liquid nitrogen using a pestle until a fine powder was obtained, then transferred to microtube containing $2 \%$ CTAB.

Total genomic DNA was extracted following the protocol described by Doyle and Doyle (1990), using $100 \mathrm{mg}$ of leaf tissue for each treatment. After maceration using one of the methods described above, the samples were incubated for 60 minutes in a water bath at $65^{\circ} \mathrm{C}$ with $700 \mu \mathrm{L}$ of preheated extraction buffer containing $698.6 \mu \mathrm{L}$ of $2 \%$ CTAB solution and 1.4 $\mu \mathrm{L}$ of $\beta$-mercaptoethanol. During the incubation procedure, the microtubes were manually stirred every 10 minutes for homogenisation. Following incubation, the microtubes were removed from the water bath and cooled to room temperature. In the fume cupboard, $600 \mu \mathrm{L}$ of chloroform and isoamyl alcohol (24:1) was added, and the microtubes were manually stirred for 5 minutes.

Centrifugation was performed at $13,000 \mathrm{rpm}$ for 15 minutes. The upper (aqueous) phase was transferred $(160 \mu \mathrm{L})$ to a new microtube. Then, 400 $\mu \mathrm{L}$ of cold isopropanol $\left(-20^{\circ} \mathrm{C}\right)$ was added, and the samples were incubated at $-20{ }^{\circ} \mathrm{C}$ for 30 minutes.

The microtubes were centrifuged at 13,000 rpm for 15 minutes, and the supernatant was discarded. The pellets were washed twice in $300 \mu \mathrm{L}$ of absolute ethanol and twice in $70 \%$ ethanol by centrifugation at 13,000 rpm for 5 and 10 minutes, respectively. The pellets were then resuspended in $50 \mu \mathrm{L}$ of TE buffer $(10 \mathrm{mM}$ Tris- $\mathrm{HCl}, \mathrm{pH} 8.0 ; 1$ $\mathrm{mM}$ EDTA), then incubated at $37{ }^{\circ} \mathrm{C}$ in an air forced circulation oven for 1 hour, and then stored in the refrigerator.

Subsequently, the samples were electrophoresed on a $0.8 \%$ agarose gel $(0.5 \mathrm{X}$ TBE buffer under 120 volts and 400 milli-amperes for 1 hour) to check DNA integrity. DNA purity indices were quantified in an $8000 \mathrm{~A}$ spectrophotometer (Metash) and the ratio of A260/A280 was used to estimate the purity of the DNA (GREEN; SAMBROOK, 2012).

The DNA was quantified in a spectrophotometer at $260 \mathrm{~nm}$ wavelength. The 
concentration of DNA was estimated from the equation: DNA concentration (ng) $=$ OD reading (Optical Density) $260 \times 50 \times$ dilution factor (SAMBROOCK et al., 1989).

To evaluate the DNA quality, polymerase chain reaction was used. Nine microsatellite markers (EE2, EE8, EE23, EE32, EE45, EE47, EE52, EE52 and EE59) developed for E. edulis (Gaiotto et al., 2001) were used. Reactions were made containing the following: $5 \mathrm{ng}$ of genomic DNA; $10 \mathrm{mM}$ Tris- $\mathrm{HCl}, 50 \mathrm{mM} \mathrm{KCl} ; 0.25 \mathrm{mM}$ of each dNTP; $0.25 \mathrm{mg} / \mathrm{mL}$ BSA (Bovine Serum Albumin); $2.0 \mathrm{mM} \mathrm{MgCl} 2 ; 0.2 \mu \mathrm{M}$ of each primer; and $1 \mathrm{U}$ of Taq DNA polymerase and sterile ultrapure water. Amplifications were performed in a thermocycler (Analitik Jena). The samples were submitted to the following amplification steps: $94^{\circ} \mathrm{C}$ for 1 minute, followed by 30 cycles at $94^{\circ} \mathrm{C}$ for 1 minute, annealing temperature set for each primer for 1 minute and $72^{\circ} \mathrm{C}$ for 1 minute, followed by a final extension step at $72^{\circ} \mathrm{C}$ for 5 minutes.

The estimates of DNA concentrations for the different treatments were subjected to analysis of variance (ANOVA) and, when significant differences were observed, the means were grouped by the Scott-Knott test at the $1 \%$ significance level. The analysis was performed using the statistical package SISVAR (FERREIRA, 2011).

\section{RESULTS AND DISCUSSION}

The general appearance of E. precatoria leaflets varied among the different storage methods (Figure 1). The leaflets kept in the refrigerator (3 to 5 days) and transport buffer (3, 5, and 7 days) displayed excellent preservation. These treatments remained similar in appearance and characteristics to the fresh leaflets (Figure 1A) and did not suffer any changes in leaf tissue. All treatments in transport buffer presented leaf turgidity similar to that of fresh tissue.

In contrast, the treatments maintained in the lyophiliser (3 days), refrigerator (7 days), and silica gel $(7,10,20$, and 30 days) showed changes in leaf tissue (Figure 1B and 1C). The leaflets stored in the lyophiliser (3 days) presented a completely dehydrated visual appearance and light green colour. The leaflets kept in the refrigerator (7 days) showed partially dehydrated tissue and the same light green colouration.

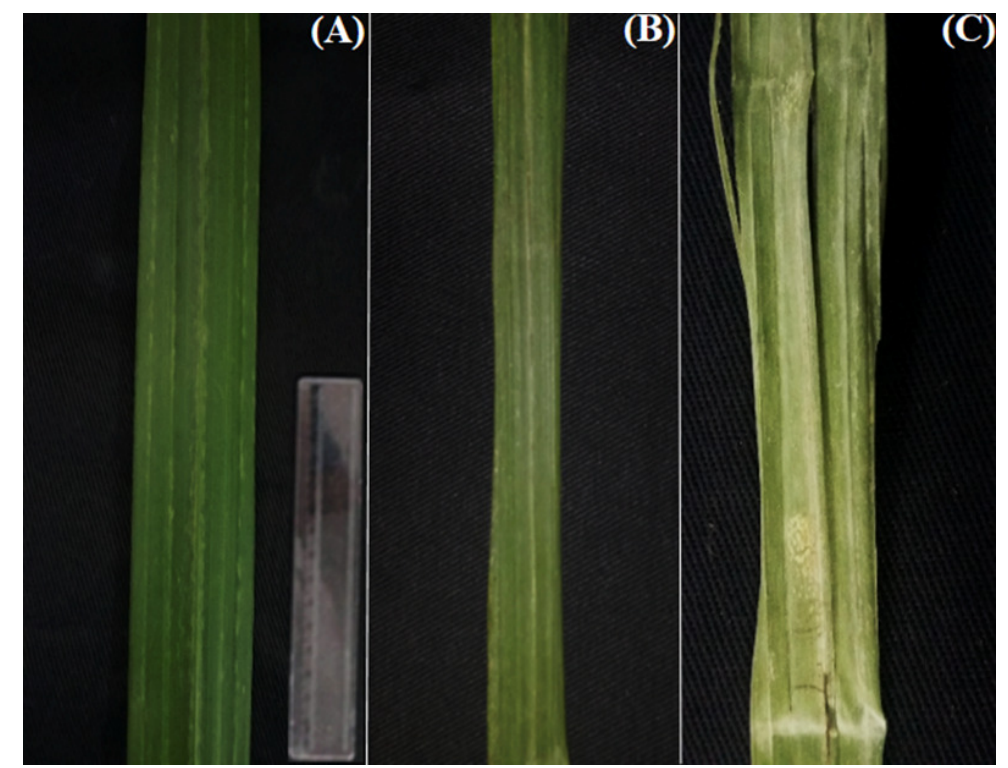

Figure 1. Euterpe precatoria leaflets in different storage treatments: A) Fresh leaflets, B) Refrigerator (7 days), and C) Silica gel (30 days).

Leaflets stored in silica gel were gradually dehydrated as the colour indicator changed. The loss of water was more noticeable in the first three days. A gradual uniform bleaching also occurred in the leaflets with deterioration in some parts (Figure 1C). The use of silica for storage is still viable since unaffected parts of the leaflets may be used for subsequent DNA extraction. The changes in colour in the leaf tissue are related to the chlorophyll loss resulting from a period of preservation and dehydration. Chlorophyll pigments are relatively unstable and sensitive to light, time, heating, oxygen, and chemical degradation (SCHIOZER; BARATA, 2007).

Our results corroborate those reported in the literature for some species of plants where the use of fresh, frozen, and cooled leaf tissue have been the predominant methodologies for preservation of 
biological material for subsequent genomic DNA extraction (SILVA et al., 2010; MESQUITA et al., 2015). In the present study, storage of leaflets in transport buffer for one week also proved to be a viable methodology for the preservation of plant tissue, since these leaflets retained the characteristics of fresh leaflets.

Despite producing colour alteration in plant tissue, the silica gel method has been commonly used in the preservation of leaf samples of palm species such as "tucumanzeiro" (A. aculeatum), "açaizeiro" (E. oleracea), and "jauari" (A. jauari) (MILANI et al., 2009; OLIVEIRA et al., 2010; OLIVEIRA et al., 2014). The silica gel storage method has several advantages over other methods, owing to its simplicity, low cost, and the minimal space required for transport and storage in the laboratory.

However, for Neotropical savanna species, the use of silica gel was not recommended for preservation of leaves prior to DNA extraction (FERES et al., 2005). However, these authors report that environmental conditions could have activated dehydration mechanisms in these plants and suggest that the silica gel preservation method may still be effective for other species (FERES et al., 2005). $E$. precatoria occurs in a different environment with high humidity.

In the present study, variation in the integrity of extracted DNA was observed among
AZÊVEDO, H. S. F. S. et al.

treatments. All liquid nitrogen treatments presented better DNA integrity than that observed in the TissueLyser® treatments. The liquid nitrogen treatment samples clearly exhibited defined fragments on the gel, without smears, indicating that DNA degradation had not occurred. Danner et al. (2011) also obtained good quality DNA from "jabuticabeira" (Plinia cauliflora) tree leaves when macerated with liquid nitrogen whereas they detected degradation in samples macerated directly in CTAB buffer. The use of liquid nitrogen to macerate leaf tissue is advantageous because it allows rapid freezing and as a result, it avoids DNA degradation (DANNER et al., 2011). However, attainment, cost, and storage are the obstacles for its use in many laboratories (IBRAHIM et al., 2010; IHASE et al., 2016), such as those located in the Amazon.

Samples macerated in the TissueLyser ${ }^{\circledR}$ presented DNA oxidation (Figure 2A). During the steps of DNA precipitation with cooled isopropanol and pellet formation by centrifugation, a dark brown colouration was observed in the samples macerated with the TissueLyser®, while the samples macerated with liquid nitrogen were clean and translucent (Figure 2B). The formation of dark DNA precipitates may occur due to the covalent attachment of oxidized polyphenols to the DNA (PETERSON et al., 1997).

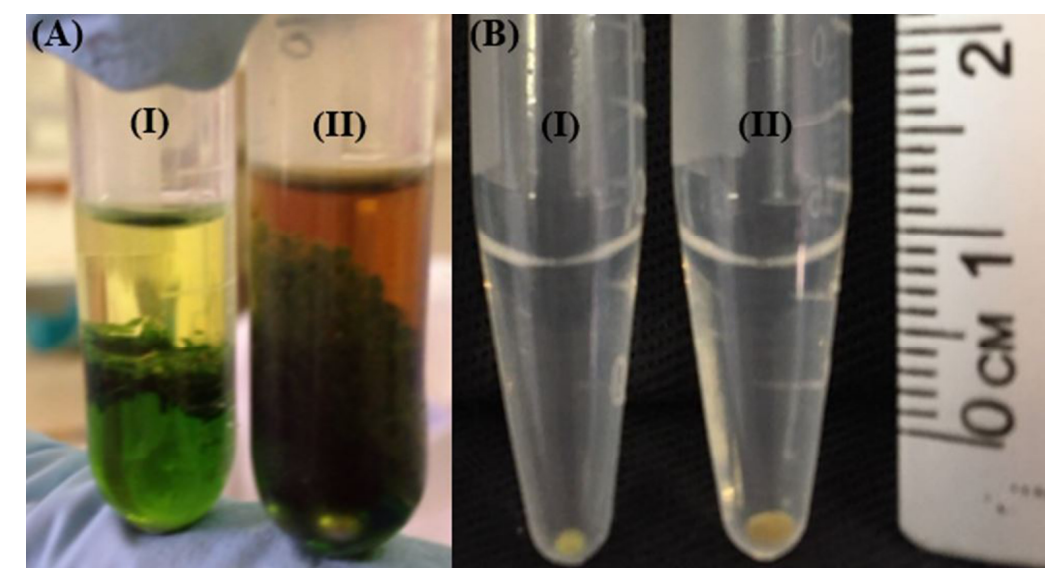

Figure 2. A) Comparative centrifugation profile of E. precatoria leaflets macerated and washed with chloroform and isoamyl alcohol: (I) macerated with liquid nitrogen, and (II) an oxidized sample obtained from TissueLyser ${ }^{\circledR}$ process. B) (I) lighter pellet produced from maceration with liquid nitrogen, in contrast to (II) darker pellet resulting from TissueLyser ${ }^{\circledR}$ maceration.

The DNA purity ranged from 1.30 to 1.70 when treatments were macerated with liquid nitrogen and from 1.30 to 1.90 when macerated with the TissueLyser® (Figure 3). 


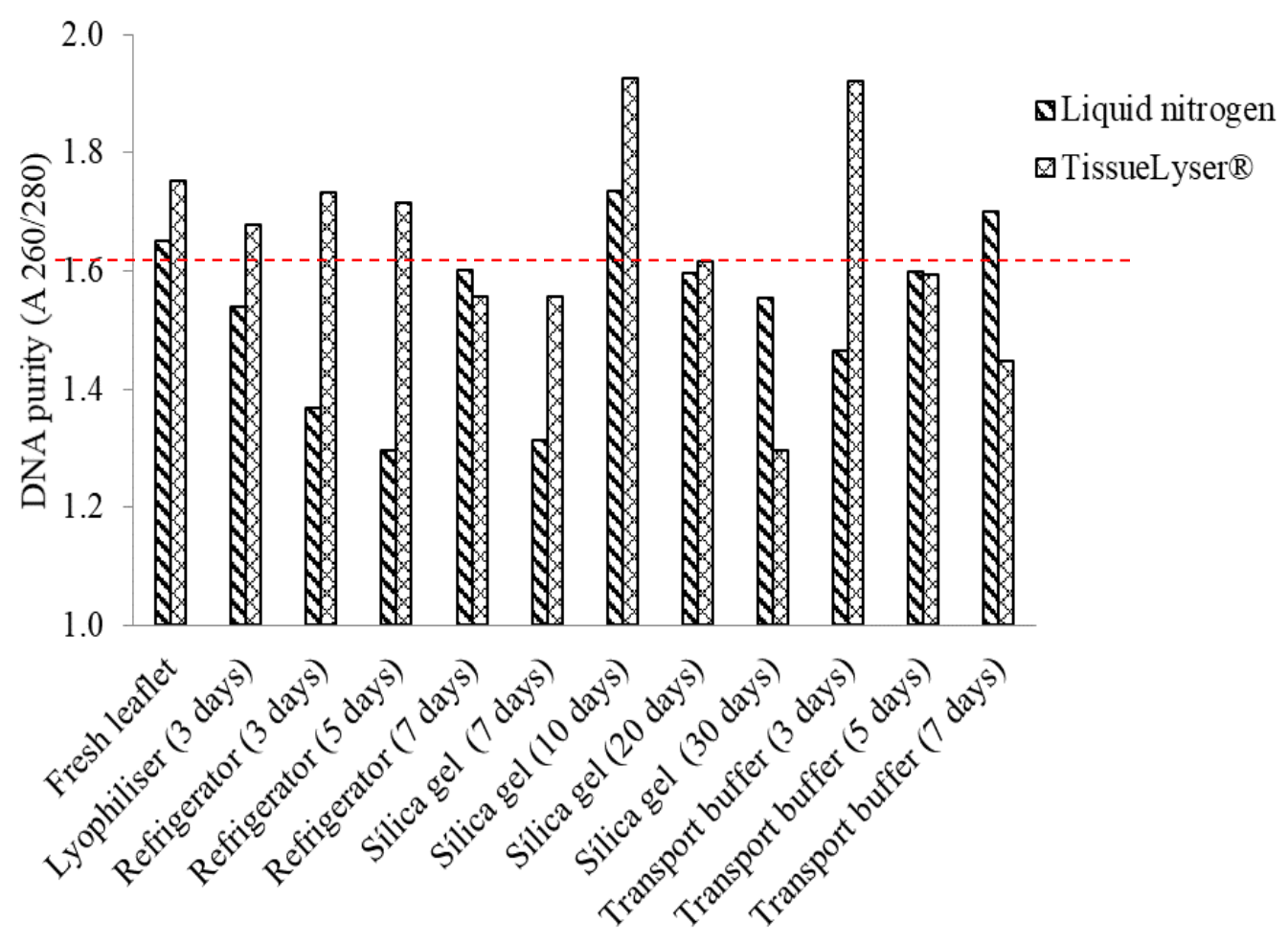

Figure 3. Analysis of purity of DNA extracted from E. precatoria leaflets from twelve types of storage and two maceration methods (liquid nitrogen and TissueLyser®).

The absence of RNA was observed in all samples. According to Green and Sambrook (2012), the recommended range for absorbance ratios (A260/A280) is 1.70 to 2.00 indicating pure DNA. The low purity of DNA (A260/A280<1.7) observed in the present study for some storage and maceration treatments may have been due to the contaminants released during cell lysis, or an insufficient number of chloroform washes. Mature leaflets have varying levels of polysaccharides, polyphenols, and other secondary metabolites that represent the main obstacles encountered in the purification of plant DNA, and require adaptations to the DNA extraction procedure (SILVA et al., 2010; SIKA et al., 2015).

Previous studies have confirmed that palm species (Elaeis guineensis, Phoenix dactylifera, Dypsis madagascariensis) that grow in tropical regions have leaves with a waxy cuticle and high fibre content that are rich in polysaccharides and polyphenols (ANGELES et al., 2005). It is known that the presence of such compounds may reduce or even inhibit the activity of DNA polymerases and restriction enzymes. The presence of these compounds in large amounts is the main issue found in the purification of genomic DNA from plant tissues (NUNES et al., 2011, SIKA et al., 2015).
In general, the use of young leaves is recommended to obtain DNA with higher purity, since these only contain low concentrations of phenolic compounds (MITTON et al., 1979). However, adult individuals of E. precatoria may reach up to $20 \mathrm{~m}$ in height and the youngest leaflets are at the top of the plant (YAMAGUCHI et al., 2015). Therefore testing of methodologies and refinement of protocols is fundamental, especially when using molecular techniques, since the quality of genomic DNA is crucial.

A significant difference in the DNA concentration obtained was observed between the storage interaction and the maceration type, with the unfolding of direct and inverse interactions (Table $1)$.

When the maceration method was analysed independently of the storage method, the TissueLyser ${ }^{\circledR}$ macerator produced higher concentrations of DNA when compared to liquid nitrogen. With TissueLyser ${ }^{\circledR}$ maceration, five distinct groups of storage methods were observed based on DNA concentration. However, when using liquid nitrogen maceration, only two groups were observed. 
Table 1. Unfolding averages of interactions between DNA concentrations extracted from Euterpe precatoria leaflets using different storage and maceration methods.

\begin{tabular}{lcc}
\hline \multicolumn{1}{c}{ Conservation and storage types } & \multicolumn{2}{c}{ Maceration method $(\mathrm{ng} / \mu \mathrm{L})$} \\
\hline Treatments & Liquid nitrogen & TissueLyser® \\
\hline Fresh leaflets & $545.00 * \mathrm{Ba}$ & $1912.50 \mathrm{Ab}$ \\
Lyophiliser (3days) & $660.00 \mathrm{Ba}$ & $2850.00 \mathrm{Aa}$ \\
Refrigerator (3 days) & $512.50 \mathrm{Aa}$ & $705.00 \mathrm{Ae}$ \\
Refrigerator (5 days) & $543.90 \mathrm{Ba}$ & $1100.00 \mathrm{Ad}$ \\
Refrigerator (7 days) & $600.00 \mathrm{Ba}$ & $1705.00 \mathrm{Ab}$ \\
Silica gel (7 days) & $362.50 \mathrm{Bb}$ & $1652.50 \mathrm{Ab}$ \\
Silica gel (10 days) & $685.00 \mathrm{Ba}$ & $1395.00 \mathrm{Ac}$ \\
Silica gel (20 days) & $537.50 \mathrm{Ba}$ & $955.56 \mathrm{Ad}$ \\
Silica gel (30 days) & $702.50 \mathrm{Aa}$ & $572.73 \mathrm{Ae}$ \\
Transport buffer (3 days) & $327.50 \mathrm{Bb}$ & $1602.50 \mathrm{Ab}$ \\
Transport buffer (5 days) & $450.00 \mathrm{Bb}$ & $827.50 \mathrm{Ae}$ \\
Transport buffer (7 days) & $285.00 \mathrm{Bb}$ & $1662.50 \mathrm{Ab}$ \\
\hline
\end{tabular}

** CV $(\%)$

*Means followed by the same letter are not statistically different from each other according to the Scott-Knott test ( $\mathrm{p} \geq 0.01$ ). **Coefficient of variation $(\mathrm{CV})$.

For the treatments involving TissueLyser ${ }^{\circledR}$ maceration, the leaflets stored in the lyophiliser (3 days) showed the highest DNA concentration, followed by fresh leaflets, refrigerator (7 days), then silica gel (7 days) and transport buffer (3 and 7 days) which did not differ statistically. Lower DNA concentrations were observed for storage in the refrigerator (3 days), silica gel (30 days), and transport buffer (5 days).

The lyophilisation methodology with TissueLyser ${ }^{\circledR}$ maceration presented the highest DNA concentration when compared to other methods of organic matter drying. The main advantage of lyophilisation is the reduction of the water content in the tissues and, consequently, the reduction of catabolic processes in the cells, since a less fluid environment decreases the catalytic activity of nucleases and proteases (NUNES et al., 2011). Lyophilised leaf tissues allow better interaction between the extraction buffer and the dry tissue. With less fluid in the tissue, there is less dilution of the extraction buffer and therefore its activity is improved (NUNES et al., 2011). The use of dehydrated tissue facilitates the disruption of the cell walls and consequently produces higher yields of DNA. Although the entire lyophilisation process requires about 72 hours for complete leaflet dehydration, its applicability is certainly satisfactory (NUNES et al., 2011; PEDRAL et al., 2015).

Mazza and Bittencout (2000) obtained DNA of good quality and quantity extracted from lyophilised Araucaria angustifolia. These authors claim that the use of a lyophiliser eliminated the need for liquid nitrogen during maceration. The results of another study showed that the combination of lyophilisation with PVP improves the quality and quantity of extracted DNA (NUNES et al., 2011).

In the present study, all TissueLyser ${ }^{\circledR}$ macerated treatments presented higher concentrations of DNA (572.73 to $2,850.00 \mathrm{ng} / \mu \mathrm{L})$ when compared to those macerated with liquid nitrogen and this can be explained by the characteristics of the equipment. Stirring at a high speed together with stainless steel spheres facilitates the disruption of the cell walls and, as a result, more cells are broken to release DNA molecules compared with liquid nitrogen maceration. This is corroborated by the high DNA concentration observed when the lyophiliser treatment was combined with TissueLyser® maceration. The tissue dehydration, the use of stainless steel spheres, and the higher agitation and velocity were determining factors in the higher yield of DNA obtained. Another advantage of the TissueLyser ${ }^{\circledR}$ equipment is the ability to macerate 48 samples at once, while with liquid nitrogen only one sample is macerated at a time.

The treatments using the lyophiliser (3 days), refrigerator $(3,5$, and 7 days), silica gel (10, 20 , and 30 days), and fresh leaflets macerated with liquid nitrogen produced the highest concentrations of DNA. The silica gel treatments (7 days) and all transport buffer treatments produced the lowest DNA concentrations. 
The DNA concentrations obtained from the silica gel treatments $(10,20$, and 30 days) were the same as those for the fresh and lyophilised leaflet samples, although the silica gel treatments did not produce satisfactory tissue preservation. The concentration of DNA extracted from Elaeis guineensis was similar to that found in the present study when using liquid nitrogen to macerate the leaf tissue, with concentrations ranging from 496.00 to $572.00 \mathrm{ng} / \mu \mathrm{L}$ (IHASE et al., 2016). The concentrations of DNA extracted from E. oleraceae ranged from 40.00 to $313.00 \mathrm{ng} / \mu \mathrm{L}$ when extracted from fresh leaves, kept frozen with ice, and macerated with liquid nitrogen (COSTA; OLIVEIRA 2002).
AZÊVEDO, H. S. F. S. et al.

All the storage and maceration treatments resulted in positive PCR amplification (Figure 4) and therefore provided satisfactory genetic material for molecular analyses. The optimal annealing temperature varied among the evaluated loci (Table 2). Loci EE41 and EE47 had the lowest annealing temperature $\left(45.8{ }^{\circ} \mathrm{C}\right)$, and locus EE45 had the highest annealing temperature $\left(57.3{ }^{\circ} \mathrm{C}\right)$. The results also confirmed the transferability of loci from $E$. edulis to E. precatoria (AZÊVEDO et al., 2017). These results indicated that DNA extracted from leaflets of $E$. precatoria did not contain contaminants such as polysaccharides and secondary metabolites, which could affect DNA quality (SIKA et al., 2015).

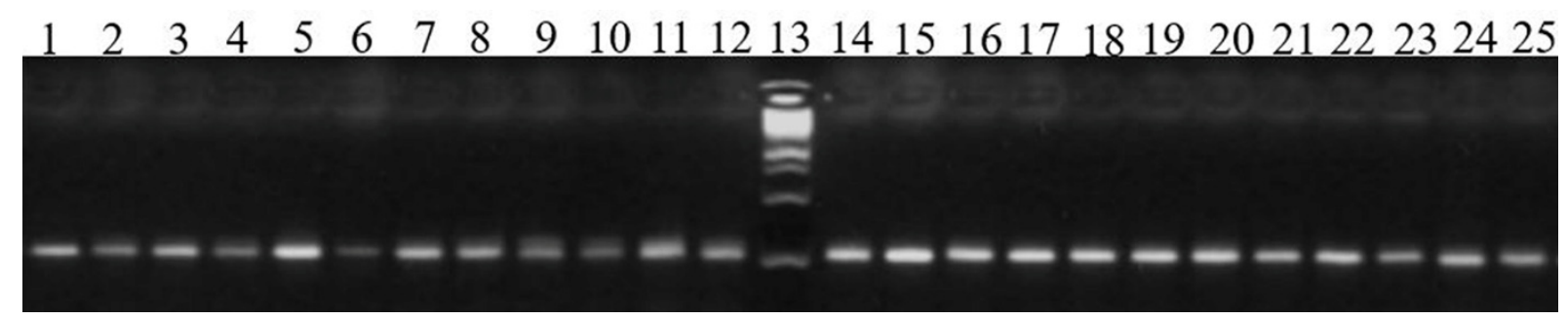

Figure 4. Agarose gel electrophoresis of Euterpe precatoria DNA amplified with microsatellite locus EE8. Lanes 1-12: twelve storage treatments macerated with TissueLyser® automatic equipment; Lane 13: label (1 kb Fermentas $\left.{ }^{\circledR}\right)$; Lanes 14-25: twelve storage treatments macerated with liquid nitrogen.

Table 2. Characteristics of nine heterologous microsatellite markers for Euterpe precatoria.

\begin{tabular}{cccc}
\hline Loci & TA $\left({ }^{\circ} \mathrm{C}\right)$ & Fragment size $(\mathrm{bp})$ & GenBank \\
\hline EE2 & 55.4 & $87-90$ & AF328879 \\
EE8 & 50.2 & $122-143$ & AF328872 \\
EE32 & 55.4 & $190-195$ & AF328883 \\
EE41 & 45.8 & $107-122$ & AF328884 \\
EE45 & 57.3 & $109-110$ & AF328887 \\
EE47 & 45.8 & $255-270$ & AF328874 \\
EE52 & 53.6 & $205-210$ & AF328888 \\
EE54 & 50.2 & $120-124$ & AF328876 \\
EE59 & 50.2 & $108-120$ & AF328885 \\
\hline
\end{tabular}

TA $\left({ }^{\circ} \mathrm{C}\right)$ : Annealing temperature; bp: Base pairs.

Several methodologies for plant DNA isolation are available. However, modifications are necessary according to the peculiarities of each species. For the species E. precatoria, the tests of storage and maceration of mature foliar tissue were important because they provide options for further studies to use simple and low-cost techniques for extraction of DNA of sufficient quality for use in genetic analyses.

\section{ACKNOWLEDGEMENTS}

This work was supported by grants from Embrapa Acre. The authors thank Coordenação de Aperfeiçoamento de Pessoal de Nível Superior (CAPES) for granting doctorate scholarships and also the colleague Eduardo Soares for the collaboration in the layout of the figures. 
RESUMO: O objetivo deste estudo foi testar a eficiência de métodos de preservação e maceração de tecidos de folíolos de Euterpe precatoria para obter DNA genômico para estudos moleculares. Os folíolos de $E$. precatoria foram coletados no campo experimental da Embrapa Acre, Brasil. O estudo foi conduzido em delineamento inteiramente casualizado com 10 repetições, em esquema fatorial $12 \times 2$, com 12 tratamentos de armazenamento (fresco; liofilizado 3 dias; geladeira 3, 5, e 7; sílica gel 7, 10, 20 e 30 dias e tampão de transporte 3, 5 e 7 dias) e dois tipos de maceração do tecido foliar (nitrogênio líquido e TissueLyserß). Para a variável concentração de DNA houve diferença estatística entre os tipos maceração e de armazenamento. $\mathrm{O}$ macerador TissueLyser® apresentou maiores concentrações de DNA quando comparado ao nitrogênio líquido. Para os tipos de armazenamento verificou-se formação de cinco grupos quando macerados TissueLyser® e dois grupos quando macerados com nitrogênio líquido. As concentrações de DNA variaram de 285,00 ng/ $\mu \mathrm{L}$ (7 dias em tampão de transporte) a 702,00 ng/ $\mathrm{LL}$ (30 dias em sílica gel) quando maceradas com nitrogênio líquido. Quando maceradas com macerador TissueLyser® variaram de 572,73 ng/ $\mu \mathrm{L}$ (30 dias em sílica gel) a 2.850,00 $\mathrm{ng} / \mu \mathrm{L}$ (3 dias em liofilizador). A pureza do DNA (A260/A280 nm) variou de 1,30 a 1,70 quando os folíolos foram macerados com nitrogênio líquido e de 1,30 a 1,90 quando macerados em macerador TissueLyser®. Apesar das variações na conservação e concentração dos tecidos foliares, todos os tratamentos foram eficazes para o isolamento do DNA e amplificaram regiões de marcadores microssatélites. Concluiu-se que folíolos de E. precatoria armazenados em liofilizador e macerados com macerador automático resultaram em DNA satisfatório para estudos moleculares.

PALAVRAS-CHAVE: Açaí-solteiro. Euterpe precatoria. Isolamento de DNA. Método CTAB.

\section{REFERENCES}

ANGELES, J. G. C.; LAURENA, A. C.; TECSON-MENDOZA, E. M. Extraction of genome DNA from lipid, polysaccharides, and polyphenols rich coconut (Cocos nucifera L.). Plant Molecular Biology Reporter, Düsseldorf, v. 23, n. 1, p. 297-298, 2005. http://dx.doi.org/10.1007/BF02772760

AZÊVEDO, H. S. F. S.; BENVINDO, F. D.; CAVALCANTE, L. N.; HAVERROTH, M.; WADT, L. H. O.; CAMPOS, T. Transferability of heterologous microsatellite loci between species of Euterpe genus. Genetics and Molecular Research, Ribeirão Preto, v. 16, n. 4, p. 1-7, 2017. http://dx.doi.org/10.4238/gmr16039825

BUSSMANN, R. W.; ZAMBRANA, N. Y. P. Facing global markets-usage changes in Western Amazonian plants: the example of Euterpe precatoria Mart. and E. oleracea Mart. Acta Societatis Botanicorum Poloniae, Warsaw, v. 81, n. 4, p. 257-281, 2012. http://dx.doi.org/10.5586/asbp.2012.032

COSTA, M. R.; OLIVEIRA, M. S. P. Extração de DNA de açaizeiro a partir de folhas. Belém: Embrapa Amazônia Oriental, 2002. 22 p. (Embrapa Amazônia Oriental. Documentos, 127).

DANNER, M. A.; SASSO, S. A. Z.; BITTENCOURT, J. V. M.; CITADIN, I. Proposta de protocolo para extração de DNA de jabuticabeira. Ciência Florestal, Santa Maria, v. 21, n. 2, p. 363-367, 2011. http://dx.doi.org/10.5902/198050983241

DOYLE, J. J.; DOYLE, J. L. Isolation of plant DNA from fresh tissue. Focus, v. 12, n. 1, p. 13-15, 1990.

FERES, F.; SOUZA, A. P.; AMARAL, M. C.; BITTRICH, V. Avaliação de métodos de preservação de amostras de plantas de Savanas Neotropicais para a obtenção de DNA de alta qualidade para estudos moleculares. Revista Brasileira de Botânica, São Paulo, v. 28, n. 2, p. 277-283, 2005.

FERREIRA, D. F. Sisvar: a computer statistical analysis system. Ciência e Agrotecnologia, Lavras, v. 35, n. 6, p. 1039-1042, 2011. http://dx.doi.org/10.1590/S0100-84042005000200008. 
GAIOTTO, F. A.; BRONDANI, R. P. V.; GRATTAPAGLIA, D. Microsatellite markers for heart of palm Euterpe edulis and E. oleracea Mart. (Palmae). Molecular Ecology Notes, Portland, v. 1, n. 1, p. 86-88, 2001. https://doi.org/10.1046/j.1471-8278.2001.00036.x

GREEN, M. R.; SAMBROOK, J. Molecular cloning: a laboratory manual. New York: Cold Spring Harbor Laboratory, 2012. 628 p.

IBRAHIM, A. A.; BAKIR, M. A.; KHAN, H. A.; AHAMED, A. A. simple method for DNA extraction from mature date palm leaves: impact of sand grinding and composition of lysis buffer. International Journal of Molecular Sciences, Fribourg, v. 11, n. 9, p. 3149-3157, 2010. https://doi.org/10.3390/ijms11093149

IHASE, O. L.; HORN, R.; ANOLIEFO, G. O.; EKE, C. R. Development of a method for DNA extraction from oil palm leaves and the effects of $\mathrm{pH}$ and ionic strength on nucleic acid quantification. Journal of Biological Methods, Beijing, v. 3, n. 2, p. 37-42, 2016. https://doi.org/10.14440/jbm.2016.80

MAZZA, M. C. M.; BITTENCOURT, J. V. M. Extração de DNA de tecido vegetal de Araucaria angustifolia (Araucariaceae). Boletim de Pesquisa Florestal, Colombo, n. 41, p. 12-17, 2000.

MESQUITA, A. C. O.; FIGUEIRÓ, A. A.; COUTO, K. R.; OLIVEIRA, M. F. Optimization of soybean DNA extraction under diferente storage and development periods. Bioscience Journal, Uberlândia, v. 31, n. 4, p. 1102-1106, 2015. http://dx.doi.org/10.14393/BJ-v31n4a2015-28343

MILANI, M.; DANTAS, F. V.; MARTINS, W. F. S. Divergência genética em mamoneira por caracteres morfológicos e moleculares. Revista Brasileira de Oleaginosas e Fibrosas, Campina Grande, v. 13, n. 2, p. $61-71,2009$.

MITTON, J. B.; LINHART, Y. B.; STURGEON, K. B.; HAMRICK, J. L. Allozyme polymorphism detected in mature needle tissue of ponderosa pine. Journal of Heredity, College Station, v. 70, n. 2, p. 86-89, 1979. https://doi.org/10.1093/oxfordjournals.jhered.a109220

NUNES, C. F.; FERREIRA, J. L.; FERNANDES, M. C. N.; BREVES, S. D. S. An improved method for genomic DNA extraction from strawberry leaves. Ciência Rural, Santa Maria, v. 41, n. 8, p. 1383-1389, 2011. http://dx.doi.org/10.1590/S0103-84782011000800014

OLIVEIRA, L. D. S.; RAMOS, S. L. F.; LOPES, M. T. G.; DEQUIGIOVANNI, G.; VEASEY, E. A.; MACÊDO, J. L. V.; BATISTA, J. S.; FORMIGA, K. M.; LOPES, R. Genetic diversity and structure of Astrocaryum jauari (Mart.) palm in two Amazon river basins. Crop Breeding and Applied Biotechnology, Viçosa, v. 14, n. 3, p. 166-173, 2014. http://dx.doi.org/10.1590/1984-70332014v14n3a25

OLIVEIRA, M. S. P.; SANTOS, J. B.; AMORIM, E. P.; FERREIRA, D. F. Variabilidade genética entre acessos de açaizeiro utilizando marcadores microssatélites. Ciência e Agrotecnologia, Lavras, v. 34, n. 5, p. 1253-1260, 2010. http://dx.doi.org/10.1590/S1413-70542010000500025.

PEDRAL, A. L.; BARBOSA, J. S.; SANTOS, G. R.; XAVIER, A. C. R. Caracterização físico-química de folhas da Moringa oleífera desidratadas por secagem convectiva e liofilização. Revista Brasileira de Produtos Agroindustriais, Campina Grande, v. 17, n. 1, p. 33-39, 2015.

PETERSON, D. G.; BOEHM, K. S.; STACK S. M. Isolation of milligram quantities of nuclear DNA from tomato (Lycopersicon esculentum), a plant containing high levels of polyphenolic compounds. Plant Molecular Biology Reporter, Düsseldorf, v. 15, n. 2, p. 148-153, 1997. http://dx.doi.org/10.1007/BF02812265

SAMBROOK, J.; FRITSCH, E. F.; MANIATIS, T. Molecular cloning: a laboratory manual. Cold New York: Spring Harbor Laboratory, 1989. 1546 p. 
SARTORETTO, L. M.; FARIAS, P. C. M. Diversidade genética e técnicas biotecnológicas. Unoesc \& Ciências, Joaçaba, v. 1, n. 2, p. 155-162, 2010.

SCHIOZER, A. L.; BARATA, L. E. S. Estabilidade de Corantes e Pigmentos de Origem Vegetal. Revista Fitos, Jacarepaguá, v. 3, n. 1, p. 1-19, 2007.

SILVA, M. N. D. Extração de DNA genômico de tecidos foliares maduros de espécies nativas do cerrado. Revista Árvore, Viçosa, v. 34, n. 6, p. 973-978, 2010. http://dx.doi.org/10.1590/S0100-67622010000600002

SIKA, K. C.; KEFELA, T.; ADOUKONOU-SAGBADJA, H.; AHOTON, L.; SAIDOU, A.; BABA-MOUSSA, L.; BAPTISTE, L. J. N. O.; KOTCONI, S. O.; GACHOMO, E. A simple and efficient genomic DNA extraction protocol for large scale genetic analyses of plant biological systems. Plant Gene, Mus, v. 1, n. 1, p. 43-45, 2015. https://doi.org/10.1016/j.plgene.2015.03.001

YAMAGUCHI, K. K. L.; PEREIRA, L. F. R.; LAMARÃO, C. V.; LIMA, E. S. Amazon acai: Chemistry and biological activities: A review. Food Chemistry, Norwich, v. 179, n. 15, p. 137-151, 2015. http://dx.doi.org/10.1016/j.foodchem.2015.01.055

YUYAMA, L. K. O.; AGUIAR, J. P. L.; SILVA FILHO, D. F.; YUYAMA, K. Caracterização físico-química do suco de açaí de Euterpe precatoria Mart. oriundo de diferentes ecossistemas amazônicos. Acta Amazonica, Manaus, v. 41, n. 4, p. 545-552, 2011. http://dx.doi.org/10.1590/S0044-59672011000400011 